Volume 5 Issue 2, September 2020: pp.109-121 Copyright @ LamLaj. Faculty of Law, Lambung Mangkurat University, Banjarmasin,

South Kalimantan, Indonesia. ISSN: 2502-3136 | e-ISSN: 2502-3128.

Open Access at: http://lamlaj.ulm.ac.id/web/

\title{
TINJAUAN YURIDIS PENGATURAN SANKSI PIDANA DALAM PERATURAN DAERAH PROVINSI GORONTALO
}

\author{
Novendri M. Nggilu \\ Fakultas Hukum Universitas Negeri Gorontalo \\ Jl. Jend. Sudirman No. 6 Kota Gorontalo \\ novendrilawfaculty@ung.ac.id
}

Submitted : 05/04/2020 Reviewed:05/08/2020 Accepted:23/09/2020

\begin{abstract}
Legal politics of the establishment of the Gorontalo provincial rules since established in 2000, still flavored criminalization, it is reflected from the regulation of criminal sanctions that not only exceed the provisions of the legislation but also errors in referring provisions that determine the qualification of an act imposed criminal sanctions or not. The purpose of this writing is to outline the arrangement of criminal sanctions in the regional regulation of Gorontalo Province. The type of research used in this study is normative research with a statute and conceptual approach. The results were found that there was a regional regulation referring not to the article that contained the act of law, but rather referring to the chapter in which are general chapters and does not contain legal acts that can be qualified as criminal acts, it is reflected in the local regulations on environmental management. In addition, there are also local regulations for which the sanction of the sanctions is exceeded by the provisions of sanctions arrangements that can be governed by local regulations, where a criminal sanction of confinement of imprisonment of 3 (three) years and a fine of Rp. 500 million, whereas the provisions of the Law on the establishment of legislation and Minister of Internal Affairs regulations about the establishment of local legal products only limit the loading of criminal sanctions maximum 6 (six) months confinement, and fines at most Rp. 50 million.
\end{abstract}

Keywords: Criminal Sanctions; Local Regulation; Politics of Law.

Abstrak: Politik hukum pembentukan Peraturan Daerah Provinsi Gorontalo sejak dibentuk tahun 2000, politik hukumnya masih bercita rasa pemidanaan, hal itu tercermin dari adanya pengaturan sanksi pidana yang bukan hanya melebihi dari ketentuan pembebanan sanksi pidana, melainkan juga kesalahan dalam merujuk ketentuan yang menentukan kualifikasi sebuah tindakan dibebankan sanksi pidana atau tidak. Tujuan penulisan ini adalah untuk menguraikan pengaturan sanksi pidana dalam Peraturan Daerah Provinsi Gorontalo. Jenis penelitian yang digunakan dalam penelitian ini adalah penelitian normatif dengan pendekatan statuta dan konseptual. Hasilnya ditemukan bahwa adanya peraturan daerah yang 
merujuk bukan pada pasal yang memuat tentang perbuatan hukum, melainkan merujuk pada BAB yang di dalamnya terdapat pasal-pasal yang umum dan tidak memuat perbuatan hukum yang dapat dikualifikasi sebagai perbuatan pidana, itu tercermin dari peraturan daerah tentang Pengelolaan Lingkungan Hidup. Di samping itu, terdapat juga peraturan daerah yang pembebanan sanksi pidananya melebihi dari ketentuan pengaturan sanksi yang dapat diatur dalam peraturan daerah, dimana pembebanan sanksi pidana kurungan 3 (tiga) tahun dan denda Rp. 500.000.000, padahal ketentuan dalam undang-undang tentang pembentukan peraturan perundang-undangan dan Permendagri tentang pembentukan produk hukum daerah hanya membatasi pembebanan sanksi pidana maksimal 6 (enam) bulan kurungan, dan denda paling banyak Rp. 50.000.000.

Kata Kunci: Peraturan Daerah; Politik Hukum; Sanksi Pidana.

\section{PENDAHULUAN}

Penegasan konstitusional tentang pilihan bentuk negara sebagai negara kesatuan (eenheidsstaat, unie) ${ }^{1}$ Indonesia merupakan sebuah kesepakatan tertinggi para pembentuk negara, sekalipun pernah mengalami ujian konstitusional pada saat dirubahnya UUD 1945 menjadi Konstitusi Republik Indonesia Serikat pada tahun 1949, meskipun demikian pengakuan terhadap daerah-daerah yang berada pada naungan Negara Indonesia masih tetap diakui. Dalam perjalanan panjang tentang dinamika Konstitusi Indonesia, penguatan tentang peranan daerah dalam pembangunan Nasional mendapatkan momentumnya melalui perubahan UUD 1945 yang terjadi pada tahun 1999-2002 yang ditandai dengan adanya lahirnya pasal yang menegasikan kewenangan pembentukan peraturan daerah bagi daerah baik pada tingkatan provinsi maupun pada tingkatan kabupaten/kota.

Penegasan Konstitusional tentang hak pemerintah daerah dalam menetapkan per-

\footnotetext{
${ }^{1}$ Mahkamah Konstitusi Republik Indonesia, Naskah Komprehensif Perubahan Undang-Undang Dasar Republik Indonesia Tahun 1945, Latar Belakang, Proses dan Hasil Pembahasan 1999-2002 (Jakarta: Sekretariat dan Kepaniteraan Mahkamah Konstitusi, 2010), 57.
}

aturan daerah dan peraturan-peraturan lain untuk melaksanakan otonomi dan tugas pembantuan $^{2}$ kemudian diderivasi lagi ke dalam Undang-Undang Nomor 12 Tahun 2011 tentang Pembentukan Peraturan PerundangUndangan (Selanjutnya disingkat UU No. 12 Tahun 2011) yang dalam Pasal 7 ayat (1) yang memuat tentang hirarki peraturan perundangundangan di Indonesia dengan menempatkan peraturan daerah baik peraturan daerah provinsi maupun kabupaten/kota menjadi bagian dari hirarki peraturan perundang-undangan.

Dalam hal materi muatan peraturan daerah, disebutkan bahwa ketentuan peraturan perundang-undangan yang dapat memuat ketentuan sanksi pidana hanyalah dibatasi pada undang-undang dan peraturan daerah, meskipun pembebanan sanksi pidana dapat dilakukan oleh undang-undang dan peraturan daerah, namun adanya pembatasan pengaturan sanksi antara sanksi pidana dalam undang-undang dan peraturan daerah dibatasi. Dalam pembebanan sanksi dalam undang-undang tidak diatur limitasi pembebanan sanksi pidana, pengaturan tentang limitasi pembebanan sanksi

\footnotetext{
2 Lihat Pasal 18 ayat (6) Undang-Undang Dasar Negara Republik Indonesia Tahun 1945, selanjutnya akan disingkat UUD NRI Tahun 1945
} 
pidana hanya berlaku pada peraturan daerah, hal ini secara tegas tercermin dalam Peraturan Menteri Dalam Negeri Nomor 80 Tahun 2015 tentang Pembentukan Produk Hukum Daerah yang secara tegas menyatakan bahwa limitasi pembebanan sanksi pidana pada peraturan daerah adalah maksimal pidana kurungan paling lama 6 (enam) bulan serta denda dibatasi paling banyak sebesar 50 (lima puluh) juta rupiah.

Meskipun secara normatif pengaturan sanksi pidana pada peraturan daerah dimungkinkan untuk diatur, akan tetapi pengaturan sanksi pidana harus dapat dimaknai sebagai norma yang bersifat ultimum remedium, ${ }^{3}$ artinya pembebanan sanksi pidana dapat dilakukan manakala tidak ada lagi atau tidak efektif lagi jenis-jenis sanksi lainnya seperti sanksi administrasi.

Jika kita breakdown ke dalam konteks Provinsi Gorontalo sebagai salah satu daerah otonom yang juga memiliki kewenangan pembentukan peraturan daerah, maka pembentukan peraturan daerah Provinsi Gorontalo dalam kurun waktu 2000-2017 terdapat sebanyak 198 Peraturan Daerah. Jumlah ini tentunya tidaklah sedikit, dan dapat dipastikan bahwa politik hukum tentang pembentukan peraturan daerah yang ada selama ini juga mengakomodir pembebanan sanksi pidana, seperti Peraturan Daerah Nomor 10 Tahun 2014 tentang Kawasan Tanpa Rokok yang mengatur sanksi pidana bagi para pelaku yang mengkonsumsi rokok pada tempat-tempat yang telah dilarang sebagaimana norma yang tertuang dalam peraturan daerah tersebut, serta peraturan daerah lainnya. Padahal jika kita

\footnotetext{
3 Nur Ainiyah Rahmawati, "Hukum Pidana Indonesia: Ultimum Remedium atau Primum Remedium," Jurnal Recidive 2, No. 1 (2013): 39-44, https://jurnal. uns.ac.id/recidive/article/view/32002
}

melihat kondisi tentang jumlah ketersediaan lembaga pemasyarakatan kita, kita diperhadapkan pada masalah tentang jumlah Lapas yang sedikit dengan masalah lainnya tentang daya tampung pelaku tindak pidana. ${ }^{4}$ Artinya, politik hukum pembentukan peraturan daerah kita saat ini menunjukkan bahwa adanya peraturan-peraturan daerah yang "bercita rasa" penghukuman pidana.

Di samping pengaturan aspek ketentuan pidana, aspek kerancuan normatif yang juga tercermin dalam pengaturan sanksi pidana dalam Peraturan Daerah Provinsi Gorontalo adalah pengaturan ketentuan pidana yang rujukan tidak merujuk pada pasal melainkan merujuk pada BAB peraturan daerah tersebut. Oleh sebab itu, tulisan ini hendak menjawab pertanyaan penelitian tentang bagaimana analisis dari perspektif yuridis tentang pengaturan sanksi pidana dalam peraturan daerah Provinsi Gorontalo.

\section{METODE}

Jenis penelitian yang digunakan dalam penelitian ini adalah jenis penelitian normative dengan pendekatan yuridis dan pendekatan konseptual. Pendekatan secara yuridis digunakan untuk menelusuri payung hukum (umbrella act) pengaturan sanksi pidana dalam peraturan daerah, sementara pendekatan konseptual digunakan untuk mengelaborasi konsep terkait teknik dalam perancangan sanksi pidana.

\footnotetext{
4 "Lembaga Pemasyarakatan Kelas II Kota Gorontalo memiliki Kapasitas 330 orang, namun saat ini jumlah warga binaan yang berada di Lembaga Pemasyarakatan tersebut mencapai 643 dengan penjaga berjumlah 8 petugas, artinya 1 petugas rata-rata mengawasi 80 warga binaan," detiknews, accessed May 18, 2020. https://news.detik.com/ berita/d-3224090/selain-over-capacity-643-napi-dilapas-gorontalo-hanya-dijaga-8-petugas.
} 
Sumber bahan hukum dalam penulisan artikel ini adalah bahan hukum primer yakni baik dalam UU Nomor 12 Tahun 2011 sebagaimana telah diubah dengan UU Nomor 15 Tahun 2019 tentang Pembentukan Peraturan Perundang-Undangan serta Permendagri Nomor 80 Tahun 2015 sebagaimana telah diubah dengan Permendagri Nomor 120 Tahun 2018 tentang Pembentukan Produk Hukum Daerah, sementara bahan hukum sekunder diperoleh dari buku atau jurnal yang terkait dengan artikel ini. Teknik pengumpulan data yang digunakan adalah Teknik pengumpulan secara kepustakaan, dengan analisis bahan hukum menggunakan teknik analisis preskriptif.

\section{ANALISIS DAN PEMBAHASAN}

Pengaturan Sanksi Pidana dalam Peraturan Daerah Provinsi Gorontalo

Pemerintah daerah merupakan subsistem dari pemerintah Negara Kesatuan Republik Indonesia. Oleh karena itu, segala tujuan dan cita-cita yang diamanatkan oleh pembukaan UUD NRI Tahun 1945 adalah juga merupakan cita-cita dan tujuan pemerintah daerah yang harus dicapai. Dengan dilaksanakannya asas desentralisasi, pemerintah daerah menjadi pemegang kendali bagi pelaksanaan pemerintah di daerah. Menurut ketentuan yang tercantum dalam Pasal 18 ayat (6) UUD NRI Tahun 1945 menetapkan, "Pemerintahan daerah berhak menetapkan peraturan daerah dan peraturanperaturan lain untuk melaksanakan otonomi dan tugas pembantuan." Peraturan Daerah merupakan salah satu dari jenis peraturan perundang-undangan yang berlaku dalam sistem ketatanegaraan Indonesia dewasa ini. Berdasarkan ketentuan Pasal 18 ayat (6) UUD NRI Tahun 1945 maka setiap daerah diberikan wewenang untuk membuat sendiri peraturan daerahnya. Undang-Undang
Nomor 23 Tahun 2014 tentang Pemerintahan Daerah, mengatur bahwa peraturan daerah di bentuk dalam rangka penyelenggaraan otonomi daerah. Provinsi/Kabupaten/Kota dan tugas pembantuan serta merupakan penjabaran lebih lanjut dari peraturan perundangan yang lebih tinggi dengan memperhatikan ciri khas masing-masing daerah. Peraturan daerah sebagai salah satu bentuk perturan perundangundangan merupakan bagian dari pembangunan sistem hukum nasional. Peraturan daerah yang baik dapat terwujud apabila didukung oleh metode dan standar yang tepat sehingga memenuhi teknis pembentukan peraturan perundang-undangan, sebagaimana diatur dalam Undang-Undang Nomor 12 Tahun 2011 tentang Pembentukan Peraturan Perundangundangan (selanjutnya disebut UU Nomor 12 Tahun 2011), menjadi landasan hukum untuk penyusunan peraturan perundang-undangan termasuk juga peraturan lokal tadi yaitu peraturan daerah yang berlaku mengikat bagi daerah tempat peraturan daerah itu dibentuk. Peraturan Daerah merupakan produk hukum daerah yang ditetapkan oleh kepala daerah atas persetujuan Dewan Perwakilan Rakyat Daerah, dan dalam pelaksanaannya berlaku secara lokal, sehingga kekuatan mengikatnya hanya pada daerah dibentuk.

Lon L. Fuller memandang dari sudut pembentuk peraturan perundang-undangan, melihat hukum sebagai alat untuk mengatur masyarakat. Tujuan pembentuk peraturan perundang-undangan akan berhasil apabila ia sampai pada tingkat tertentu memerhatikan asas-asas yang diambilnya dalam principles of legality, ${ }^{5}$ yaitu:

1. Tidak boleh mengandung sekadar kepu-

5 Esmi Warassih, Pranata Hukum Sebuah Telaah Sosiologis (Semarang: Badan Penerbit Universitas Diponegoro, 2012), 50 
tusan-keputusan yang bersifat ad hoc;

2. Peraturan yang sudah dibuat harus diumumkan;

3. Tidak boleh ada peraturan yang berlaku surut, oleh karena apabila yang demikian itu tidak ditolak, maka peraturan itu tidak bisa dipakai untuk menjadi pedoman tingkah laku;

4. Peraturan-peraturan harus disusun dalam rumusan yang bisa dimengerti;

5. Suatu sistem tidak boleh mengandung peraturan-peraturan yang bertentangan satu sama lain;

6. Peraturan-Peraturan tidak boleh mengandung tuntutan yang melebihi apa yang dapat dilakukan;

7. Peraturan-Peraturan harus tetap, tidak boleh terdapat pertentangan satu sama lain;

8. Harus terdapat kesesuaian antara tindakan-tindakan para pejabat hukum dan peraturan-peraturan yang telah dibuat.

Desain yuridis mengenai pembentukan peraturan perundang-undangan di Indonesia senantiasa mengacu pada Undang-Undang Nomor 12 Tahun 2011 tentang Tata Cara Pembentukan Peraturan Perundang-Undang, tidak terkecuali dalam hal pembentukan peraturan daerah di Indonesia.

Apabila pembentukan peraturan daerah dihubungkan dengan konsep otonomi daerah, maka secara umum terdapat beberapa alasan esensi program pembentukan peraturan daerah dalam penyusunan peraturan daerah, yaitu: ${ }^{6}$

1. Sarana sinkronisasi dan harmonisasi den-

${ }^{6}$ Eva N.A.M. Sihombing, "Problematika Penyusunan Program Pembentukan Peraturan Daerah," Jurnal Legislasi Indonesia 13, No. 3 (2016): 285-295, http://e-jurnal.peraturan.go.id/index.php/jli/article/ view/156 gan perencanaan pembangunan daerah. Dalam konstruksi ini, kegiatan pembangunan di daerah sudah terencana melalui RPJMD, rencana kerja SKPD sesuai dengan visi dan misi daerah. Oleh sebab itu, program pembentukan peraturan daerah yang disusun setiap tahun anggaran harus mengacu pada perencanaan pembangunan daerah, sehingga norma yang diperlukan untuk mendukung otonomi sejalan dengan arah kebijakan pembangunan daerah;

2. Sarana menampung menyalurkan aspirasi masyarakat daerah. Dengan adanya program pembentukan peraturan daerah, yang dikaji secara mendalam antara DPRD dan kepala daerah diharapkan ada skala prioritas untuk melahirkan peraturan daerah yang berupa pemberdayaan (empowering)bagi masyarakat daerah sejalan dengan arah kebijakan pembangunan. Dalam praktik seringkali peraturan daerah yan dilahirkan lebih dominan bersifat pungutan dan organisasi perangkat daerah, sedangkan peraturan daerah yang berkaitan dengan pemberdayaan masyarakat adakalanya terabaikan;

3. Sarana meningkatkan sinergi antara DPRD dan kepala daerah dalam melahirkan produk hukum, dalam jenis peraturan daerah. Sejalan dengan division of power yang dianut dalam sistem ketatanegaraan Indonesia, dalam penyelenggaraan pemerintah daerah peraturan daerah lahir atas kerjasama antara DPRD dengan kepala daerah. Oleh sebab itu program pembentukan peraturan daerah tentu merupakan wujud hubungan kerjasama yang bersifat kemitraan antara DPRD dengan kepala daerah dalam membangun daerah berdasarkan "cheks and balances sys- 
tems", apalagi harus dipahami lahirnya sebuah peraturan daerah terkait dengan anggaran, evaluasi dan kajian, penyusunan naskah akademik dan sebagainya;

4. Sarana mewujudkan peraturan daerah yang baik. Melalui program pembentukan peraturan daerah akan dapat meminimalisir munculnya peraturan daerah yang tumpeng tindih atau bermasalah, karena dalam mewujudkan peraturan daerah yang didasarkan pada program pembentukan peraturan daerah, tentu dilakukan melalui pengkajian dan penyelarasan peraturan, apalagi dewasa ini pembentukan peraturan daerah harus disertai naskah akademik, sehingga seharusnya peraturan daerah yang disusun secara terencana akan dapat dipertanggungjawabkan secara ilmiah.

Sebagaimana diketahui, bahwa pembentukan peraturan daerah harus memenuhi beberapa tahapan pembentukannya, yaitu tahap perencanaan, penyusunan, pembahasan, penetapan, pengesahan, dan pengundangan. ${ }^{7}$ Dalam UU Nomor 12 Tahun 2011 khususnya Pasal 15 ayat (1), disebutkan bahwa materi muatan mengenai sanksi pidana hanya dapat dimuat dalam Undang-Undang, Peraturan Daerah Provinsi, dan Peraturan Daerah Kabupaten/Kota. Meskipun peraturan daerah dimungkinkan memuat ketentuan sanksi pidana, namun pengaturan tentang sanksi pidana tersebut merupakan pengaturan bersyarat, artinya dimungkinkannya pengaturan sanksi pidana terdapat pembatasan pembebanan sanksi kurungan yang dibatasi maksi-

\footnotetext{
Muhammad Suharjono, "Pembentukan Peraturan Daerah Yang Responsif Dalam Mendukung Otonomi Daerah," Jurnal Ilmu Hukum DIH 10, No. 19 (2014): 21-37, http://jurnal.untag-sby.ac.id/index.php/dih/ article/view/281/0
}

mal 6 (enam) bulan serta denda maksimal 50 (lima puluh) juta rupiah. Hal ini sebagaimana diatur di dalam Pasal 15 ayat (2) UU Nomor 12 Tahun 2011.

Ketentuan tersebut secara derivatif juga ditemukan dalam Peraturan Menteri Dalam Negeri Nomor 80 Tahun 2015 sebagaimana telah dirubah dengan Peraturan Menteri Dalam Negeri Nomor 120 Tahun 2018 tentang Pembentukan Produk Hukum Daerah, bahkan dalam ketentuan Pasal 5 permendagri tersebut dikonstruksikan terdapat 3 (tiga) jenis sanksi yang dimungkinkan diatur dalam peraturan daerah, yaitu jenis sanksi kurungan yang juga dibatasi maksimal selama 6 (enam) bulan, jenis sanksi denda yang maksimal 50 (lima puluh) juta, serta jenis sanksi administratif dan rehabilitasi.

Ketentuan tentang pengaturan sanksi pidana dalam peraturan daerah tersebut menjadi fokus dan pertimbangan daerah juga untuk menjadikan peraturan daerah bisa semakin kuat dan operasional serta ditaati oleh masyarakat, sebab dalam ketentuan peraturan daerah pasti memuat ketentuan hak dan kewajiban serta larangan, yang juga tak jarang berujung pada sanksi pidana. ${ }^{8}$

Menurut Suharyo, perkembangan tentang penggunaan sanksi pidana untuk menertibkan masyarakat melalui peraturan perundangundangan cukup pesat, baik itu dalam bentuk pengaturan dalam undang-undang maupun peraturan daerah, itu terlihat dari banyaknya pengaturan sanksi pidana dalam undang-undang dan peraturan daerah yang diatur secara khusus dalam bab ketentuan pidana. ${ }^{9}$ Maksud

\footnotetext{
${ }^{8}$ Suharyo, "Pembentukan Peraturan Daerah, Dan Penerapan Sanksi Pidana Serta Problematikanya," Jurnal Rechtsvinding, Media Pembinaan Hukum Nasional 4, No. 3 (2015): 323, https://rechtsvinding. bphn.go.id/ejournal/index.php/jrv/article/view/15

9 Ibid.
} 
pilihan penggunaan kebijakan hukum pengaturan sanksi pidana dalam peraturan daerah untuk menertibkan masyarakat tidaklah berjalan semulus yang diharapkan, pemerintah daerah sendiri tak jarang diperhadapkan pada persoalan mengenai pelanggaran peraturan daerah yang itu terjadi dan dilakukan oleh masyarakat, elit birokrasi dan politik di daerah, serta kondisi ketidakberdayaan polisi pamong praja dalam melakukan penegakan peraturan daerah, ${ }^{10}$ serta keterbatasan jumlah penyidik pegawai negeri sipil menjadikan penegakan sanksi pidana merupakan aspek yang problematik lingkup peraturan daerah.

Dalam perumusan ketentuan pidana dalam peraturan daerah, perlu diperhatikan unsur-unsur yang harus dipenuhi, yaitu :11

a. Penyebutan subjek pidana, baik yang bersifat umum (setiap orang) maupun orang tertentu atau kelompok orang tertentu (orang asing, dan lain-lain);

b. Penyebutan sifat perbuatan pidana, apakah sengaja atau kelalaian. Pertimbangan sengaja ataukah kelalaian dalam pelanggaran ketentuan pidana, tetap dikembalikan pada institusi hakim pengadilan, artinya hakim yang nanti akan memeriksa dan mengadili yang mempunyai kewenangan menilai dan memutuskan apakah benar ada unsur kelalian atau memang sengaja, sehingga berat dan ringannya suatu hukuman, akan ditentukan dari ada atau tidaknya unsur kelalaian dan/ atau kesengajaan;

c. Penyebutan perbuatan yang diancam

10 Ibid.

${ }^{11}$ Muhammad Fauzan, Djumadi, Riris Ardhanariswari, "Perumusan Ketentuan Pidana Dalam Pembentukan Peraturan Daerah (Studi di Kabupaten Purbalingga)," Jurnal Dinamika Hukum 8, No. 1 (2008): 154-165, http://dinamikahukum.fh.unsoed.ac.id/index.php/ JDH/article/view/60 pidana, baik dengan cara menunjuk pasal, atau pasal-pasal yang diancam pidana maupun rumusan konkrit mengenai perbuatannya;

d. Penyebutan jenis perbuatan pidana apakah kejahatan ataukah pelanggaran. Penyebutan jenis pidana ini bertalian dengan sistem hukum pidana Indonesia.

e. Penyebutan lama atau besarnya ancaman maksimum. Untuk pidana badan disebutkan paling lama, sementara untuk pidana denda disebutkan paling banyak.

Rumusan ketentuan pidana harus menyatakan secara tegas apakah pidana yang dijatuhkan bersifat kumulatif, alternatif, atau kumulatif alternatif.

Jika di breakdown ke dalam kondisi eksisting Provinsi Gorontalo, terdapat 33 peraturan daerah yang memuat ketentuan pidana di dalamnya, yaitu: 
Tabel 1.

Peraturan Daerah yang Memuat Sanksi Pidana

\begin{tabular}{|c|c|c|}
\hline No & Nomenklatur Perda & Rumusan Sanksi Pidana \\
\hline 1 & $\begin{array}{l}\text { Perda No. } 5 \text { Tahun } 2003 \text { Retribusi Jasa Atas } \\
\text { Pemberian Pekerjaan }\end{array}$ & $\begin{array}{l}\text { Pidana Kurungan paling lama } 3 \text { (tiga) bulan dan } \\
\text { denda paling banyak } 4 \text { (empat) kali jumlah retribusi }\end{array}$ \\
\hline 2 & $\begin{array}{l}\text { Perda No. } 10 \text { Tahun } 2003 \text { tentang Pencegahan } \\
\text { Maksiat }\end{array}$ & $\begin{array}{l}\text { Pidana Kurungan paling lama } 6 \text { (enam) bulan dan } \\
\text { denda paling banyak } 5 \text { (lima) juta rupiah }\end{array}$ \\
\hline 3 & $\begin{array}{l}\text { Perda No. } 4 \text { Tahun } 2004 \text { tentang Pengelolaan } \\
\text { Kualitas Air dan Pengendalian Pencemaran } \\
\text { Lingkungan }\end{array}$ & $\begin{array}{l}\text { Pidana Kurungan paling lama } 6 \text { (enam) bulan dan } \\
\text { denda paling banyak } 5 \text { (lima) juta rupiah }\end{array}$ \\
\hline 4 & $\begin{array}{l}\text { Perda No. } 3 \text { Tahun } 2004 \text { tentang Rencana Umum } \\
\text { Ketenagalistrikan Daerah Provinsi Gorontalo }\end{array}$ & $\begin{array}{l}\text { Rumusan sanksi merujuk pada ketentuan peraturan } \\
\text { perundang-undangan }\end{array}$ \\
\hline 5 & $\begin{array}{l}\text { Perda No. } 5 \text { Tahun } 2004 \text { tentang Pengeolaan } \\
\text { Lingkungan Hidup di Provinsi Gorontalo }\end{array}$ & $\begin{array}{l}\text { Pidana Kurungan paling lama } 6 \text { (enam) bulan dan } \\
\text { denda paling banyak } 5 \text { (lima) juta rupiah }\end{array}$ \\
\hline 6 & $\begin{array}{l}\text { Perda No. } 1 \text { Tahun } 2006 \text { tentang Pengelolaan } \\
\text { Wilayah Pesisir Secara Terpadu }\end{array}$ & $\begin{array}{l}\text { Pidana Kurungan paling lama } 6 \text { (enam) bulan dan } \\
\text { denda paling banyak } 50 \text { (lima puluh) juta rupiah }\end{array}$ \\
\hline 7 & $\begin{array}{l}\text { Perda No. } 2 \text { Tahun } 2006 \text { tentang Pengelolaan } \\
\text { Ekosistem Terumbu Karang }\end{array}$ & $\begin{array}{l}\text { Pidana Kurungan paling lama } 6 \text { (enam) bulan dan } \\
\text { denda paling banyak } 50 \text { (lima puluh) juta rupiah }\end{array}$ \\
\hline 8 & $\begin{array}{l}\text { Perda No. } 1 \text { Tahun } 2008 \text { tentang Pengelolaan } \\
\text { Danau Limboto }\end{array}$ & $\begin{array}{l}\text { Pidana Kurungan paling lama } 6 \text { (enam) bulan dan } \\
\text { denda paling banyak } 50 \text { (lima puluh) juta rupiah }\end{array}$ \\
\hline 9 & $\begin{array}{l}\text { Perda No. } 3 \text { Tahun } 2011 \text { tentang Retribusi } \\
\text { Pemakaian Kekayaan Daerah Pada Balai } \\
\text { Konstruksi/Laboratorium Uji Material Dinas } \\
\text { Pekerjaan Umum Provinsi Gorontalo }\end{array}$ & $\begin{array}{l}\text { Pidana Kurungan paling lama } 3 \text { (tiga) bulan dan } \\
\text { denda paling banyak } 3 \text { (tiga) kali jumlah retribusi } \\
\text { terutang. }\end{array}$ \\
\hline 10 & $\begin{array}{l}\text { Perda No. } 4 \text { Tahun } 2011 \text { Tentang RTRW Provinsi } \\
\text { Gorontalo }\end{array}$ & $\begin{array}{l}\text { Pidana Kurungan paling lama } 3 \text { (tiga) tahun dan } \\
\text { denda paling banyak } 500 \text { (lima ratus) juta rupiah }\end{array}$ \\
\hline 11 & Perda No. 5 Tahun 2011 tentang Pajak Daerah & $\begin{array}{l}\text { Pidana Kurungan paling lama } 1 \text { dan } 2 \text { tahun dan } \\
\text { denda paling banyak } 2 \text { serta } 4 \text { kali jumlah pajak } \\
\text { terutang }\end{array}$ \\
\hline 12 & $\begin{array}{l}\text { Perda No. } 6 \text { Tahun } 2012 \text { tentang Retribusi } \\
\text { Pelayanan Kesehatan Pada UPT Dinas Balai } \\
\text { Laboratorium Kesehatan Daerah Provinsi } \\
\text { Gorontalo }\end{array}$ & $\begin{array}{l}\text { Merujuk pada ketentuan peraturan perundang- } \\
\text { undangan }\end{array}$ \\
\hline 13 & $\begin{array}{l}\text { Perda No. } 8 \text { Tahun } 2012 \text { tentang Penyelenggaraan } \\
\text { Program Jaminan Kesehatan Semesta }\end{array}$ & $\begin{array}{l}\text { Merujuk pada ketentuan sanksi pada peraturan } \\
\text { perundang-undangan }\end{array}$ \\
\hline 14 & $\begin{array}{l}\text { Perda No. } 1 \text { Tahun } 2013 \text { tentang pelayanan } \\
\text { Publik }\end{array}$ & $\begin{array}{l}\text { Pidana Kurungan paling lama } 6 \text { (enam) bulan dan } \\
\text { denda paling banyak } 50 \text { (lima puluh) juta rupiah }\end{array}$ \\
\hline 15 & $\begin{array}{l}\text { Perda No. } 2 \text { tahun } 2013 \text { tentang Pemanfaatan } \\
\text { Laboratorium Kesehatan Hewan dan Kesehatan } \\
\text { Masyarakat Veteriner pada Dinas Perkebunan } \\
\text { dan Peternakan Provinsi Gorontalo }\end{array}$ & $\begin{array}{l}\text { Pidana Kurungan paling lama } 6 \text { (enam) bulan dan } \\
\text { denda paling banyak } 50 \text { (lima puluh) juta rupiah }\end{array}$ \\
\hline 16 & $\begin{array}{l}\text { Perda No. } 3 \text { Tahun } 2013 \text { tentang Pengelolaan } \\
\text { Sampah }\end{array}$ & $\begin{array}{l}\text { Pidana Kurungan paling lama } 6 \text { (enam) bulan dan } \\
\text { denda paling banyak } 50 \text { (lima puluh) juta rupiah }\end{array}$ \\
\hline 17 & $\begin{array}{l}\text { Perda No. } 10 \text { Tahun } 2013 \text { tentang Retribusi } \\
\text { Penjualan Produksi Usaha Daerah }\end{array}$ & $\begin{array}{l}\text { Pidana Kurungan paling lama } 3 \text { (tiga) bulan dan } \\
\text { denda paling banyak } 3 \text { kali jumlah retribusi terutang }\end{array}$ \\
\hline 18 & $\begin{array}{l}\text { Perda No. } 3 \text { Tahun } 2014 \text { tentang Penanggulangan } \\
\text { Bencana }\end{array}$ & $\begin{array}{l}\text { Pidana Kurungan paling lama } 3 \text { (tiga) bulan dan } \\
\text { denda paling banyak } 50 \text { (lima puluh) juta rupiah }\end{array}$ \\
\hline
\end{tabular}


19 Perda No. 4 Tahun 2014 tentang Penyelenggara Merujuk pada ketentuan sanksi pada peraturan Program Jaminan Kesehatan Daerah yang perundang-undangan

Terintegrasi dengan Program Jaminan

Kesehatan Nasional

20 Perda no. 5 Tahun 2014 tentang Pencegahan Pidana Kurungan paling lama 6 (enam) bulan dan dan Penanggulangan HIV dan AIDS di Provinsi denda paling banyak 50 (lima puluh) juta rupiah Gorontalo

21 Perda No. 6 Tahun 2014 tentang Pembinaan dan Pidana Kurungan paling lama 3 (tiga) bulan dan Pengawasan industry Rumah Tangga Pangan denda paling banyak 50 (lima puluh) juta rupiah

22 Perda No. 8 Tahun 2014 tentang Retribusi Pidana Kurungan paling lama 3 (tiga) bulan dan Pelayan Kesehatan Rumah Sakit Umum Daerah denda paling banyak 3 kali jumlah retribusi terutang dr. Hasri Ainun Habibie

23 Perda No. 10 Tahun 2014 tentang Kawasan Pidana Kurungan paling lama 3 (tiga) bulan dan Tanpa Rokok denda 100.000-1.000.000

24 Perda No. 1 Tahun 2015 tentang Pengelolaan Pidana Kurungan paling lama 6 (enam) bulan dan Air Tanah denda paling banyak 50 (lima puluh) juta rupiah

25 Perda No. 10 Tahun 2015 tentang Pidana Kurungan paling lama 6 (enam) bulan dan Penyelenggaraan Bantuan Hukumuntuk denda paling banyak 50 (lima puluh) juta rupiah Masyarakat Miskin

26 Perda No. 16 Tahun 2015 tentang Pengawasan Pidana Kurungan paling lama 3 (tiga) bulan dan dan Pengendalian Peredaran Minuman denda paling banyak 50 (lima puluh) juta rupiah Beralkohol

27 Perda No. 4 Tahun 2016 tentang perlindungan Pidana Kurungan paling lama 3 (tiga) bulan dan dan Pengelolaan Lingkungan Hidup denda paling banyak 50 (lima puluh) juta rupiah

28 Perda No. 7 Tahun 2016 tentang Pengelolaan Pidana Kurungan paling lama 6 (enam) bulan dan Ekosistem Mangrove denda paling banyak 50 (lima puluh) juta rupiah

29 Perda No. 8 Tahun 2016 tentang Retribusi Pidana Kurungan paling lama 3 (tiga) bulan dan Perpanjangan Izin Mempekerjakan Tenaga denda paling banyak 3 kali retribusi terutang Kerja Asing

30 Perda No. 9 Tahun 2017 tentang Rencana Tata Merujuk pada ketentuan sanksi pada peraturan Ruang Kawasan Strategis Danau Limboto perundang-undangan

31 Perda No. 1 Tahun 2018 tentang Retribusi Pidana Kurungan paling lama 3 (tiga) bulan dan Layanan Pendidikan dan Pemakaian denda paling banyak 3 kali retribusi terutang

32 Perda No. 4 Tahun 2018 tentang Rencana Merujuk pada ketentuan sanksi pada peraturan Zonasi Wilayah Pesisir dan Pulau-Pulau Kecil perundang-undangan Gorontalo

33 Perda No. 1 Tahun 2019 tentang Penyelenggaraan Pidana Kurungan paling lama 3 (tiga) bulan dan Ketenteraman, Ketertiban Umum, dan denda paling banyak 50 (lima puluh) juta rupiah Perlindungan Masyarakat

\section{Sumber data: Biro Hukum Provinsi Gorontalo}

Dari 33 peraturah daerah tersebut, terdapat aspek yang menunjukkan kelalaian dalam perancangan khususnya tentang aspek ketentuan pidana, yang dapat diuraikan sebagai berikut:

a. Terdapatnya peraturan daerah yang ketentuan pidananya tidak mengkualifisir secara jelas perbuatan yang akan dipi- dana. Hal itu tercermin dalam 2 (dua), yaitu pertama, Perda Nomor 5 Tahun 2004 tentang Pengelolaan Lingkungan Hidup di Provinsi Gorontalo pada Pasal 19 menyebutkan bahwa "barang siapa yang melanggar ketentuan perizinan lingkungan sebagaimana dimaksud BAB $\mathrm{V}$ peraturan daerah ini dapat diancam 
dengan pidana kurungan 6 (enam) bulan atau denda 50.000.000", serta kedua, Perda Nomor 4 Tahun 2004 tentang Pengelolaan Kualitas Air dan Pengendalian Pencemaran Lingkungan yang pada Pasal 38 menyebutkan bahwa "barang siapa yang melanggar ketentuan perizinan sebagaimana dimaksud BAB IX diancam dengan kurungan paling lama 6 bulan dan denda paling banyak 50.000.000" dalam ketentuan normative, mestinya kualifikasi perbuatan yang dibebankan sanksi merujuk pada Pasal, bukanlah pada BAB yang di dalamnya terdapat banyak pasal yang sifatnya bukanlah mengatur tentang perbuatan hukum. Mestinya ketentuan ini merinci pasal-pasal apa saja yang menjadi rujukan pembebanan pidana, bukan memukul rata pada satu bab.

b. Terdapatnya peraturan daerah yang memuat ketentuan sanksi melebihi dari apa yang dipersyaratkan oleh UndangUndang Nomor 12 Tahun 2011 serta Peraturan Menteri Dalam Negeri Nomor 80 Tahun 2015 tentang Pembentukan Produk Hukum Daerah khususnya Pasal 5 yang secara tegas menyatakan bahwa Peratruan Daerah dapat memuat ancaman pidana kurungan paling lama 6 (enam) bulan atau pidana denda paling banyak 50.000.000 (lima puluh juta rupiah). Memang secara yuridis, dalam Peraturan Menteri Dalam Negeri ini disebutkan adanya kemungkinan pengaturan sanksi melebihi dari ketentuan tersebut sepanjang memang pengaturan ketentuan pidana dalam peraturan daerah merujuk pada ketentuan pidana dalam undangundang yang melandasi pembentukan isi atau meteri dari peraturan daerah tersebut. Nyatanya jika di-breakdown ke dalam
Peraturan Daerah Provinsi Gorontalo, terdapat 2 (dua) peraturan daerah yang memuat ketentuan pidana melebihi dari 6 (enam) bulam dan denda 50.000.000 (lima puluh juta rupiah), yaitu Peraturan Daerah Nomor 4 Tahun 2011 tentang rencana Tata Ruang Wilayah khususnya Pasal 129 yang memuat sanksi pidana paling lama 3 (tiga) tahun dan denda paling banyak 500.000.000 (lima ratus juta rupiah), jika kita merujuk pada ketentuan pidana dalam Undang-Undang Nomor 26 Tahun 2007 Tentang Penataan Ruang memuat ketentuan pidana penjara paling lama 5 (lima) tahun dan denda paling banyak 500.000.000 (lima ratus juta rupiah), serta Perda No. 5 Tahun 2011 tentang Pajak Daerah yang memuat sanksi pidana kurungan 1-2 tahun. Hal ini menunjukkan bahwa ketentuan pidana yang tercantum dalam kedua peraturan daerah tersebut bertentangan dengan ketentuan Permendagri Nomor 80 Tahun 2015 khususnya Pasal 5 ayat (2) dan ayat (3).

Pola pembentukan peraturan daerah yang sebagaimana diuraikan pada bagian sebelumnya mencerminkan betapa politik hukum pembentukan peraturan daerah bercita rasa pemidanaan, kondisi ini sejatinya sangat kontras dengan kondisi-kondisi yang dihadapi oleh pemerintah dengan infrastruktur pola pembinaan bagi setiap warga negara yang melakukan pelanggaran dan kejahatan dimana rumah tahanan yang menjadi tumpuan tidak lagi ideal menampung jumlah pelaku kejahatan yang sangat besar, sehingga pola politik hukum pembentukan peraturan daerah tidak mesti diarahkan pada pola pembentukan yang bercita rasa pemidanaan, melainkan perlu adanya transformasi paradigma pendekatan yang perlu ditempuh. Pendekatan sebagaima- 
na dimaksud di antaranya :

1) Memaksimalkan pengaturan sanksi administrasi khususnya uang paksa. Pengaturan ketentuan uang paksa ini diharapkan di samping menekan kontribusi warga binaan di lembaga pemasyarakatan, juga sekaligus memberikan efek jera kepada masyarakat dengan memberikan uang paksa yang besarannya sesuai dengan ketentuan peraturan perundangundangan dengan jumlah paling banyak 50.000.000 yang tetap mempertimbangkan kualifikasi pelanggaran hukum yang dilakukan. selain itu, pendekatan ini juga akan meningkatkan pendapatan daerah yang dihasilkan dari uang paksa atas tindakan pelanggaran peraturan daerah yang dilakukan oleh setiap orang.

2) Membuat peraturan teknis lainnya sebagai pelaksanaan peraturan daerah yang telah dibentuk. Tidak bisa dipungkiri bahwa pembentukan Peraturan Gubernur sebagai peraturan pelaksana lebih cenderung pada pembentukan yang terkait dengan kebijakan langsung dari Gubernur misalnya terkait Peraturan Gubernur tentang Tunjangan, Penggunaan Kederaan Operasional Daerah, sementara Peraturan Gubernur yang merupakan peraturan pelaksana dari peraturan daerah yang dibentuk, utamanya yang diperintahkan secara ekspresif verbis dalam peraturan daerah masih sangat sedikti, hal ini menyebabkan beberapa peraturan daerah tersebut kurang efektifatau tidak implementatif. Faktor penghambat inilah yang perlu dipecahkan melalui politik hukum pembentukan peraturan daerah ke depan harus sudah menyiapkan draf Peraturan Gubernur yang disusun oleh Tim Penyusun Naskah Akademik dan Rancangan
Peraturan Daerah sehingga memudahkan pihak eksekutif utamanya Biro Hukum Pemerintah Provinsi Gorontalo. ${ }^{12}$

3) Membuat standar operasional prosedur bagi Satuan Polisi Pamong Praja serta Penyidik Pegawai Negeri Sipil yang ditugaskan untuk melakukan penyidikan atas pelanggaran yang dilakukan, serta kualifikasi yang pelanggaran beserta jenis penjatuhan denda atau uang paksa atas terjadinya pelanggaran peraturan daerah. SOP bagi Satuan Polisi Pamong Praja juga dimaksudkan agar Satpol PP dapat melaksanakan secara tegas, konstisten dan kontinyue sehingga penegakan peraturan daerah dapat berjalan dengan maksimal.

4) Dengan pendekatan yang disebutkan di atas, politik hukum pembentukan Pertauran Daerah Provinsi Gorontalo yang masih banyak bercita rasa pemidanaan dapat bertransformasi menjadi politik hukum pembentukan peraturan daerah yang baik.

\section{PENUTUP}

Politik hukum pembentukan Peraturan Daerah Provinsi Gorontalo masih mencerminkan sebuah politik hukum pembentukan peraturan daerah yang bercita rasa pemidanaan, terlebih teknis penormaannya memiliki kekeliruan, dimana adanya pengaturan sanksi pidana yang melebihi ketentuan yang dibolehkan oleh peraturan perundang-undangan serta terdapatnya beberapa ketentuan sanksi pidana pada peraturan daerah yang tidak me-

\footnotetext{
${ }^{12}$ Novendri M. Nggilu, Desain Politik Hukum Pembentukan Peraturan Daerah Provinsi Gorontalo Guna Mewujudkan Good Regulation (Gorontalo: Penelitian Kolabratif Fakultas Hukum Universitas Negeri Gorontalo, 2019), 61
} 
nentukan kualifikasi tindak pelanggaran yang dilakukan mencerminkan terjadinya adanya obscure norm terkait dengan ketentuan pidana dalam peraturan daerah tersebut.

Oleh sebab itu, perlu dilakukannya revisi terhadap peraturan daerah khususnya tentang penegasan kualifikasi jenis pelanggaran yang berkonsekuensi sanksi pidana, jangan memukul rujukan $\mathrm{BAB}$ melainkan rujukan pasal, sehingga penerapan ketentuan pidana tidak akan menimbulkan penafsiran yang luas, perlunya pembentukan peraturan gubernur sebagai peraturan pelaksana dari peraturan daerah yang telah dibentuk sehingga peraturan daerah yang telah dibentuk dengan biayai yang tidak sedikit tersebut dapat implementatif, serta perlunya pembentukan Standar Operasional Prosedur bukan hanya Satuan Polisi Pamong Praja guna penegakan peraturan daerah, namun juga untuk Penyidik Pegawai Negeri Sipil.

\section{BIBLIOGRAFI}

\section{Buku}

Esmi Warasih. Pranata Hukum Sebuah Telaah Sosiologis. Semarang: Badan Penerbit Universitas Diponegoro, 2012.

Mahkamah Konstitusi. Naskah Komprehensif Perubahan Undang-Undang Dasar Republik Indonesia Tahun 1945, Latar Belakang, Proses dan Hasil Pembahasan 1999-2002. Jakarta: Sekretariat dan Kepaniteraan Mahkamah Konstitusi, 2010.

Novendri M Nggilu. Desain Politik Hukum Pembentukan Peraturan Daerah Provinsi Gorontalo Guna Mewujudkan Good Regulation. Gorontalo: Penelitian Kolaboratif Pendanaan Fakultas Hukum Uni- versitas Negeri Gorontalo, 2019.

\section{Jurnal}

Faujan, Muhammad (Ed). "Perumusan Ketentuan Pidana Dalam Pembentukan Peraturan Daerah (Studi di Kabupaten Purbalingga)" Jurnal Dinamika Hukum 8, No. 1 (2008): 154-165. http://dinamikahukum.fh.unsoed.ac.id/index.php/JDH/ article/view/60

Nur Ainiyah Rahmawati, "Hukum Pidana Indonesia: Ultimum Remedium atau Primum Remedium", Jurnal Recidive 2, No. 1 (2013): 39-44. https://jurnal.uns. ac.id/recidive/article/view/32002

Sihombing, N.A.M, Eva. "Problematika Penyusunan Program Pembentukan Peraturan Daerah" Jurnal Legislasi Indonesia 13, No. 3 (2016): 285-296. http://e-jurnal.peraturan.go.id/index.php/jli/article/ view/156

Suharjono, Muhammad. "Pembentukan Peraturan Daerah Yang Responsif Dalam Mendukung Otonomi Daerah" DiH : Jurnal Ilmu Hukum 10, No. 19 (2014): 21 37. http://jurnal.untag-sby.ac.id/index. $\mathrm{php} / \mathrm{dih} /$ article/view/281/0

Suharyo. "Pembentukan Peraturan Daerah dan Penerapan Sanksi Pidana Serta Problematikanya" Jurnal Rechtsvinding, Media Pembinaan Hukum Nasional 4, No. 3 (2015): 431-447. https://rechtsvinding. bphn.go.id/ejournal/index.php/jrv/article/ view/15

\section{Internet}

"Selain Over Capacity, 643 Napi di Lapas Gorontalo Hanya Dijaga 8 Petugas" detik news. Accessed 18 May, 2020. https:// news.detik.com/berita/d-3224090/selainover-capacity-643-napi-di-lapas-gorontalo-hanya-dijaga-8-petugas 


\section{Peraturan Perundang-Undangan}

Undang Undang Dasar Negara Republik Indonesia Tahun 1945

Undang Undang Nomor 12 Tahun 2011 sebagaimana telah diubah dengan Undang Undang Nomor 15 Tahun 2019 tentang Pembentukan Peraturan Perundang-undangan 